\title{
Characteristics and enhanced antioxidant activity of glycated Morchella esculenta protein isolate
}

\author{
Qiang ZHANG ${ }^{1,2}$, Caie WU ${ }^{1 *}$, Gongjian FAN ${ }^{1}$, Tingting $\mathrm{LI}^{1}$, Xia WEN ${ }^{2}$
}

\begin{abstract}
Morchella esculenta (L) Pers. is a highly valued edible and medicinal fungus that remains underutilized. For this study, the effects of glycation treatment on antioxidant activity and characteristics of the M. esculenta protein isolate (MPI) were investigated via the Maillard reaction. Conjugation between MPI and xylose was proven via UV-vis, FT-IR, intrinsic fluorescence analysis, and SDS-PAGE. Amino acid analysis revealed involvement of lysine, arginine and tyrosine in MPI, forming a covalent cross-link with xylose. Differential scanning calorimetry (DSC) results showed that glycated MPI $\left(\mathrm{MPI}_{\mathrm{G}}\right)$ possesses a more favorable thermal stability compared to native MPI (MPI $\mathrm{N}_{\mathrm{N}}$ ), heated MPI (MPI $\left.{ }_{\mathrm{H}}\right)$ and an unheated mixture of MPI and xylose $\left(\mathrm{MPI}-\mathrm{X}_{\mathrm{M}}\right)$. $\mathrm{MPI}_{\mathrm{G}}$ exhibited significantly enhanced antioxidant activity compared to $\mathrm{MPI}_{\mathrm{N}}, \mathrm{MPI}_{\mathrm{H}}$, and $\mathrm{MPI}-\mathrm{X}_{\mathrm{M}}$. These results indicate $\mathrm{MPI}_{\mathrm{G}}$ can serve as a promising novel source of nutraceutical and functional ingredients that exert antioxidant activity.
\end{abstract}

Keywords: Maillard reaction; Morchella esculenta protein; xylose; thermal stability; antioxidant activity.

Practical Application: Glycated Morchella esculenta protein isolate can potentially be used as a natural protein antioxidant for healthcare and food industry.

\section{Introduction}

Morchella esculenta (L.) Pers. is an excellent edible and medicinal mushroom with a delicate fragrance, containing numerous biologically active compounds, such as proteins, carbohydrates, fats, and vitamins (Meng et al., 2010). The protein content of M. esculenta, accounts for $32.7 \%$ of the dry weight of the fruiting body (García-Pascual et al., 2006), contains all essential amino acids, and is comparable to the Food and Agriculture Organization of the United Nations (FAO) standard (LeDuy et al., 1974). Thus, M. esculenta is an excellent source for the development of nutraceutical and functional foods, but has not been extensively harnessed for human consumption.

Over the last few years, antioxidants have become an indispensable supplement of the nutritional world as a result of their favorable effect on the maintenance of human health and food quality (Rajendran et al., 2014). Protein antioxidants, compared to other natural antioxidants, present additional advantages when utilized in functional foods, due to their capability to provide additional nutritional value and other preferred functional properties such as foaming, emulsifying, gelling and solubility attributes (Spotti et al., 2014a; You et al., 2014). The mechanisms of protein antioxidants largely depend on their acid composition and specific conformation (Yin et al., 2014a). Therefore, the antioxidant activity of proteins can be improved via structural modification, which can disrupt the tertiary structure of the proteins and thus enhance solvent accessibility of amino acid residues, potentially burying antioxidants within the protein molecules (Elias et al., 2008). Physical, chemical or enzymatic treatments are frequently used methods. However, several of them utilize poisonous chemical surfactants and are not suitable for applications in the food industry.

Glycation, also known as Maillard reaction (MR), has generally been considered an efficient and safe way to modify proteins (Liu et al., 2012a). MR occurs spontaneously during food processing, cooking, and storage, mainly due to a reaction between the carbonyl groups of reducing sugars and the amino groups of amino acids, peptides, or proteins (Tu et al., 2015). MR usually produces a wide range of products with variable colors, aromas, and odors. It can also significantly enhance the physicochemical and functional properties of food proteins (Kim \& Shin, 2015; Oliver et al., 2006). MR is expected to be widely applied in the food, biomaterials and pharmaceutical sciences (Spotti et al., 2014b). MR is dependent on protein conformation and saccharide characteristics, such as viscosity, hydrophilicity, chain length, and number of linkages (Zhang et al., 2014). Several proteins, such as ovalbumin (Huang et al., 2012), soy proteins (Xue et al., 2013), whey proteins (Liu et al., 2014), and peanut proteins (Liu et al., 2012b) have been conjugated via MR with varied sugars, in order to improve their functionality with a particular focus on their antioxidant activities. However, the characteristics and antioxidant capabilities of Maillard reaction products (MRPs) that can be derived from the M. esculenta protein isolate (MPI)-xylose model system have not been studied, even though the MPI contains a sufficiently high ratio of lysine, which has a free $\varepsilon$-amino group and is therefore easy to undergo MR. 
This study aimed to prepare MPI-xylose conjugates via the MR as well as to investigate their molecular characteristics and antioxidant activity. Consequently, the present work will help to provide a theoretical basis for the practical application of glycated MPI as an antioxidant in the nutraceutical and functional food ingredients field.

\section{Materials and methods}

\subsection{Chemicals}

2,2'-azinobis-(3-ethylbenzothiazoneline-6-sulfonic acid) (ABTS) and 2,2-Diphenyl-1-picrylhydrazyl (DPPH) were purchased from Sigma Chemical Co. (St. Louis, MO, USA). All other chemicals and reagents were obtained from Sinopharm Chemical Reagent Co., Ltd. (Shanghai, China).

\subsection{Strain and culture}

The culture of M. esculenta (ACCC 50537) used in this study was purchased from the Agricultural Culture Collection of China, Beijing, China. Stock cultures were maintained on slants of synthetic potato dextrose agar (PDA) and subcultured every two months.

Liquid fermentation technology was used to produce the M. esculenta mycelia. M. esculenta 50537 was originally cultivated in a Petri dish containing PDA medium at $25^{\circ} \mathrm{C}$ for 7 days, before it was inoculated with a size of $0.5 \mathrm{~cm}^{2}$ to $250 \mathrm{~mL}$ Erlenmeyer flasks that contain $100 \mathrm{~mL}$ of fresh medium (potato $100 \mathrm{~g} / \mathrm{L}$, dextrose $30 \mathrm{~g} / \mathrm{L}$, peptone $1 \mathrm{~g} / \mathrm{L}$, yeast extract $5 \mathrm{~g} / \mathrm{L}, \mathrm{KH}_{2} \mathrm{PO}_{4} 1 \mathrm{~g} / \mathrm{L}$ and $\mathrm{MgSO}_{4} \cdot 7 \mathrm{H}_{2} \mathrm{O} 1 \mathrm{~g} / \mathrm{L}$ ) and incubated on a rotary shaker for 3 days at $150 \mathrm{r} / \mathrm{min}$ and $25^{\circ} \mathrm{C}$.

\subsection{Extraction of MPI}

The M. esculenta culture of the fermentation broth was filtered through gauze, washed thoroughly with distilled water, then lyophilized and powdered. The M. esculenta mycelia powder $(100 \mathrm{~g})$ was suspended in $\mathrm{NaOH}$ solution $(\mathrm{pH} 12.0)$ at a ratio of 1:40 (w/v). The mixture was then incubated for $1 \mathrm{~h}$ at $45^{\circ} \mathrm{C}$, the resulting suspension was centrifuged for $20 \mathrm{~min}$ at $4000 \mathrm{~g}$, the $\mathrm{pH}$ of the supernatant was adjusted to 4.1 , using $2 \mathrm{M} \mathrm{HCl}$ and then centrifuged for $20 \mathrm{~min}$ at $4000 \mathrm{~g}$. The obtained precipitate was collected and then dissolved in distilled water. The dispersion was adjusted to $\mathrm{pH} 7.0$ using $1.0 \mathrm{M} \mathrm{NaOH}$, and subsequently freeze-dried to produce the MPI product.

\subsection{Preparation of glycated MPI}

Glycated MPI $\left(\mathrm{MPI}_{\mathrm{G}}\right)$ was prepared following the method of Li et al. (2009) with some modifications. The glycation system consisted of MPI (1.0 g) and xylose (1.0 g), dissolved in $100 \mathrm{~mL}$ distilled water and adjusted to $\mathrm{pH} 11.0$ with $4 \mathrm{M} \mathrm{NaOH}$. Aliquots of $20 \mathrm{~mL}$ were then transferred to $25 \mathrm{~mL}$ sealed screw-top test tubes and incubated for $40 \mathrm{~min}$ in a water bath at $100{ }^{\circ} \mathrm{C}$. Immediately subsequent to this, the aliquots were cooled in an ice bath for all subsequent analyses. Control experiments were also conducted. The heated MPI without xylose (heated control) was named MPI ${ }_{\mathrm{H}}$, the unheated mixture of MPI and xylose was named MPI- $\mathrm{X}_{\mathrm{M}}$, native MPI and xylose with a concentration of $1 \%(\mathrm{w} / \mathrm{v})$ were named $\mathrm{MPI}_{\mathrm{N}}$ and $\mathrm{XYL}_{\mathrm{N}}$, respectively. $\mathrm{MPI}_{\mathrm{H}}$, MPI- $\mathrm{X}_{\mathrm{M}}, \mathrm{MPI}_{\mathrm{N}}$, and $\mathrm{XYL}_{\mathrm{N}}$ all had the same $\mathrm{pH}$ values as the glycation system.

\subsection{Spectrum analysis}

The UV-vis spectra of the samples were obtained with a spectrophotometer (model UV-3600, Shimazdu, Japan). Sample solutions, forty-fold diluted with distilled water, were placed in quartz cuvettes, and absorbance was recorded over a range of 200-500 nm, using a $1 \mathrm{~nm}$ interval. Fourier transform infrared (FT-IR) spectra at transmittance mode were performed using an online Nicolet 380 FT-IR spectrophotometer (Thermo Scientific Brand, America). All samples were freeze-dried, ground, mixed with $\mathrm{KBr}$ powder and pressed into pellets; then, the spectra were obtained in the $4000-400 \mathrm{~cm}^{-1}$ range with a resolution of $4 \mathrm{~cm}^{-1}$. The intrinsic emission fluorescence spectra of samples were obtained with a fluorescence spectrophotometer (model F-4600, Hitachi, Japan). Twenty-fold diluted sample solutions were prepared in $20 \mathrm{mM}$ phosphate buffer ( $\mathrm{pH}$ 7.4). The excitation wavelength was $290 \mathrm{~nm}$, and emission spectra were recorded from 300 to $400 \mathrm{~nm}$ with a constant slit of $5.0 \mathrm{~nm}$ for both excitation and emission.

\subsection{SDS - polyacrylamide gel electrophoresis (SDS - PAGE)}

SDS-PAGE was performed according to the discontinuous buffer system of Laemmli (1970) using 5\% stacking gel and 12\% running gel with a mini-Protean II electrophoresis apparatus (Bio-Rad Laboratories, Richmond, CA). The samples were diluted at a ratio of $1: 1$ with the loading buffer $(0.125 \mathrm{M}$ Tris- $\mathrm{HCl}, \mathrm{pH} 6.8$, containing $4.0 \%(\mathrm{w} / \mathrm{v})$ SDS, $0.02 \%(\mathrm{w} / \mathrm{v})$ bromophenol blue, $20 \%$ $(\mathrm{v} / \mathrm{v})$ glycerol and $5 \%(\mathrm{v} / \mathrm{v}) \beta$ - mercaptoethano). The solutions were then heated in boiling water for $3 \mathrm{~min}$ and centrifuged at $8000 \mathrm{~g}$ for $10 \mathrm{~min}$ prior to electrophoresis. $20 \mu \mathrm{L}$ of each sample were loaded onto the gel. Low molecular weight markers (14.4-97.4 kDa, Shanghai Shengzheng Biotechnology Co., Ltd. Shanghai, China) were used as reference. Electrophoresis was run at $20 \mathrm{~mA}$ in the stacking gel and at $30 \mathrm{~mA}$ in the separating gel until the tracking dye reached the bottom of the gel. Gels were stained with Coomassie Brilliant Blue R250 and destained via $40 \%$ methanol and $10 \%$ acetic acid.

\subsection{Amino acid analysis}

The amino acid composition of samples was analyzed after hydrolysis with $6 \mathrm{M} \mathrm{HCl}$ for $24 \mathrm{~h}$ and at $110^{\circ} \mathrm{C}$ in vacuum sealing tubes. An Automatic Amino acid analyzer (model L-8900A, Hitachi, Tokyo, Japan) was used, expressing the amino acid content in $\mathrm{mg} / \mathrm{g}$ of protein.

\subsection{Differential scanning calorimetry (DSC)}

Thermal properties of freeze-dried samples were determined with a Pyris Diamond differential scanning calorimeter (Perkin Elmer Model 7, USA). The sample with a weight of $3.6 \mathrm{mg}$ was placed in an aluminum DSC pan; then, the pan was hermetically sealed and heated from $25^{\circ} \mathrm{C}$ to $180^{\circ} \mathrm{C}$, employing a heating rate of $10^{\circ} \mathrm{C} / \mathrm{min}$ under nitrogen flow $(20 \mathrm{~mL} / \mathrm{min})$. 
The thermal parameters (onset, $\mathrm{T}_{\mathrm{o}}$; peak, $\mathrm{T}_{\mathrm{p}}$; conclusion, $\mathrm{T}_{\mathrm{c}}$; enthalpy change, $\Delta \mathrm{H}$ ) were calculated from the thermograms with instrument's Pyris software (version 9.0.2). In case of $\mathrm{MPI}_{G}$ and MPI- $\mathrm{X}_{\mathrm{M}}$, the MPI and xylose proportion $(1: 1, \mathrm{w} / \mathrm{w})$ were taken into account when computing the results.

\subsection{Antioxidant activity assay}

\section{Total antioxidant activity and reducing power}

Total antioxidant activity was determined as described by Salla et al. (2016), and the reducing power was evaluated according to the method published by Yang et al. (2014).

\section{Hydrogen peroxide scavenging activity}

The hydrogen peroxide scavenging activity was assessed spectrophotometrically, using the method described by Al-Amiery et al. (2015) but with a slight modification: $0.25 \mathrm{~mL}$ of the sample was mixed with hydrogen peroxide $(1.0 \mathrm{~mL}$, $40 \mathrm{mM}$ ) prepared in $0.2 \mathrm{M}$ phosphate buffer (at $\mathrm{pH}$ 7.4), and phosphate buffer was added to reach a total volume of $4 \mathrm{~mL}$. The absorbance value of this reaction mixture was measured in the dark at $230 \mathrm{~nm}$ after $10 \mathrm{~min}$ incubation at room temperature. The hydrogen peroxide scavenging activity was quantified using Equation 1:

Scavenging activity $(\%)=\left[A_{0}-\left(A_{1}-A_{2}\right)\right] / A_{0}$

where $A_{0}$ is the absorbance without sample, $A_{1}$ is the absorbance in the presence of the sample and $\mathrm{A}_{2}$ is the absorbance without hydrogen peroxide.

\section{Nitrite-scavenging activity}

The nitrite scavenging activity was measured using the method described by Fu et al. (2014) but with minor modifications: $1 \mathrm{~mL}$ of each sample was mixed with $1.0 \mathrm{~mL} \mathrm{NaNO}(5 \mu \mathrm{g} / \mathrm{mL})$ and $1.0 \mathrm{~mL}$ distilled water; The mixture was incubated at $37^{\circ} \mathrm{C}$ for $30 \mathrm{~min}$ and then $2 \mathrm{~mL}$ of sulfanilic acid $(0.4 \%$, w/v, prepared in $20 \%$ hydrochloric acid) were added. The mixture was left at room temperature for $5 \mathrm{~min}$; then, $1 \mathrm{~mL} \mathrm{~N}$-ethylenediamine $(0.2 \%, \mathrm{w} / \mathrm{v})$ were added and the mixture was further incubated for $15 \mathrm{~min}$ at room temperature. The absorbance value of the reaction mixture was measured at $538 \mathrm{~nm}$ against deionized water, and the nitrite scavenging activity was calculated with Equation 2:

Scavenging activity $(\%)=\left[\left(A_{0}-A_{1}\right) / A_{0}\right] \times 100$

where $A_{0}$ and $A_{1}$ represent the absorbance without and with sample present, respectively.

\section{Free radical scavenging activity}

Four models were adapted to evaluate the in vitro free radical scavenging activity of samples. The DPPH scavenging activity was measured using DPPH as a free radical model and the ABTS scavenging activity was measured via an ABTS assay
(Zhuang et al., 2013). The superoxide radical scavenging activity was determined using the pyrogallol autoxidation method (Liu et al., 2013) and the hydroxyl radical scavenging activity was measured via the spectrophotometric salicylic acid method (Zhuang et al., 2013).

\subsection{Statistical analysis}

All data are presented as mean \pm standard deviation (SD). All statistical analysis of the obtained data was performed with SPSS software (Version 19.0). Differences between the means were compared via Tukey's test with a 95\% confidence limit $(P<0.05)$.

\section{Results and discussion}

\subsection{UV-vis spectroscopy}

UV-Vis spectra were measured over the range of 200-500 nm for MPI ${ }_{\mathrm{N}}, \mathrm{MPI}_{\mathrm{H}}, \mathrm{MPI}-\mathrm{X}_{\mathrm{M}}$, and $\mathrm{MPI}_{\mathrm{G}}$ and results are shown in Figure 1. Two major absorption peaks were observed at $230 \mathrm{~nm}$ and $270 \mathrm{~nm}$ and the intensity and position of these bands were similar for $\mathrm{MPI}_{\mathrm{N}}, \mathrm{MPI}_{\mathrm{H}}$, and MPI-X $\mathrm{M}^{\text {. }}$ Compared to $\mathrm{MPI}_{\mathrm{N}^{\prime}}$, virtually no changes were found for $\mathrm{MPI}_{\mathrm{H}}$ and MPI-X $\mathrm{X}_{\mathrm{M}}$, while MPI $_{G}$ exhibited a slight absorbance red shift and considerably higher peak intensities. The obtained results agreed with Liu et al. (2014), who reported an increase in absorbance as well as a red shift in the absorption spectra occurring when whey protein isolate and glucose were conjugated via MR.

\subsection{FT-IR spectroscopy}

FT-IR spectroscopy is a practical technique to identify protein-saccharide systems, as there are a number of areas in the map that are easily identified, where chemical fingerprints of saccharides and proteins do not apparently overlap (Farhat et al., 1998). The FT-IR spectra of MPI ${ }_{\mathrm{N}}, \mathrm{MPI}_{\mathrm{H}}, \mathrm{MPI}-\mathrm{X}_{\mathrm{M}}, \mathrm{MPI}_{\mathrm{G}}$, and $\mathrm{XYL}_{\mathrm{N}}$ are shown in Figure 2. The absorption bands at 1653, 1543 and $1240 \mathrm{~cm}^{-1}$ in the spectrum of MPI ${ }_{\mathrm{N}}$ were attributed to amide $\mathrm{I}(\mathrm{C}=\mathrm{O}$ stretch), amide II (N-H bend and C-N stretch) and amide III (C-N stretching and $\mathrm{N}-\mathrm{H}$ deformation), respectively. The intensity of these regions in $\mathrm{MPI}_{\mathrm{G}}$ was lower than those in $\mathrm{MPI}_{\mathrm{N}}, \mathrm{MPI}_{\mathrm{H}}$, and MPI- $\mathrm{X}_{\mathrm{M}}$, revealing that $-\mathrm{NH}_{2}$ groups in $\mathrm{MPI}_{\mathrm{N}}$ might be consumed during MR (Wang et al., 2013).

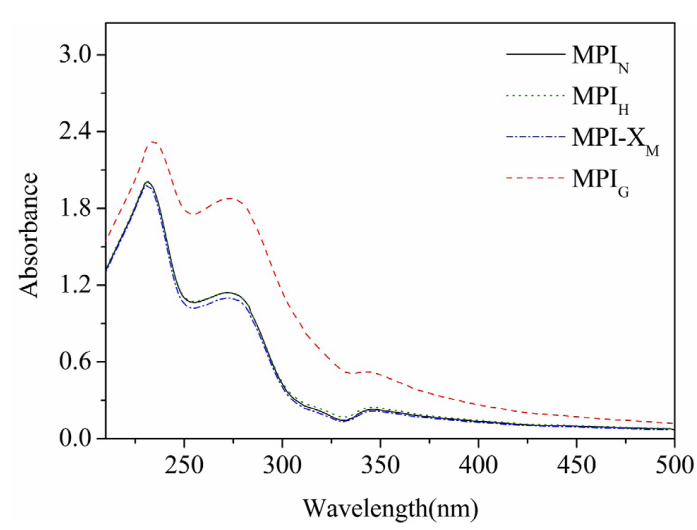

Figure 1. UV-vis spectra of $M P I_{N}, M_{H}, M P I-X_{M}$, and $M P I_{G}$. 
The peaks at the regions of $1180-953 \mathrm{~cm}^{-1}$ in the spectrum of $\mathrm{XYL}_{\mathrm{N}}$ corresponded to "saccharide" bands (stretch of C-C and $\mathrm{C}-\mathrm{O}, \mathrm{C}-\mathrm{H}$ bond). The absorptions in this region were stronger in $\mathrm{MPI}_{\mathrm{G}}$, than in $\mathrm{MPI}_{\mathrm{N}}$ and $\mathrm{MPI}_{\mathrm{H}}$, but weaker than in MPI- $\mathrm{X}_{\mathrm{M}}$ and $\mathrm{XYL}_{\mathrm{N}}$, indicating attachment of $\mathrm{XYL}_{\mathrm{N}}$ to the $\mathrm{MPI}_{\mathrm{N}}$ during MR (Wang et al., 2013). In addition, the wavenumber range of $3700-3000 \mathrm{~cm}^{-1}$ in $\mathrm{XYL}_{\mathrm{N}}$ corresponds to free -OH; the absorption in this region of $\mathrm{MPI}_{\mathrm{G}}$ was enhanced in comparison to MPI and $\mathrm{MPI}_{\mathrm{H}}$, and decreased compared to MPI- $\mathrm{X}_{\mathrm{M}}$ and $\mathrm{XYL}_{\mathrm{N}}$, suggesting protein conjugation with sugar (Geng et al., 2014). All of these phenomena indicate that $\mathrm{MPI}_{\mathrm{N}}$ and $\mathrm{XYL}_{\mathrm{N}}$ formed the graft copolymer via covalent bonding during MR.

\subsection{Intrinsic fluorescence}

Fluorescent spectral analysis has been widely used for the characterization of the MR. The intrinsic fluorescence spectra of $\mathrm{MPI}_{\mathrm{N}}, \mathrm{MPI}_{\mathrm{H}}, \mathrm{MPI}-\mathrm{X}_{\mathrm{M}}$, and $\mathrm{MPI}_{\mathrm{G}}$ are presented in Figure 3. The $\mathrm{MPI}_{\mathrm{N}}$ revealed a wavelength of maximum emission $\left(\mathrm{K}_{\max }\right)$ at $341 \mathrm{~nm}$. MPI ${ }_{\mathrm{H}}$ and MPI- $\mathrm{X}_{\mathrm{M}}$ exhibited slightly lower fluorescence intensities relative to that of MPI ${ }_{N}$ and showed no shift in their $\mathrm{K}_{\max }$ indicating that heating and adding of xylose may have a partial effect on the tertiary structure of MPI, but likely without the occurence of $\mathrm{MR}$, since the polarity of the environment surrounding Trp residues affects $\mathrm{K}_{\max }$ due to the glycation modification (Sun et al., 2006). MPI $_{G}$ exhibited significantly lower fluorescence intensity than $\mathrm{MPI}_{\mathrm{N}}$ with a marked red shift of the maximum emission, which is in agreement with previous reports (Guo \& Xiong, 2013; Huang et al., 2012), demonstrating

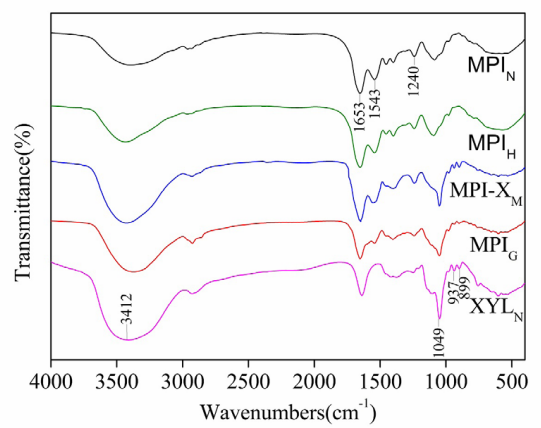

Figure 2. FT-IR spectra of $M P I_{N}, M P I_{H}, M P I-X_{M}, M P I_{G}$, and $X L_{N}$.

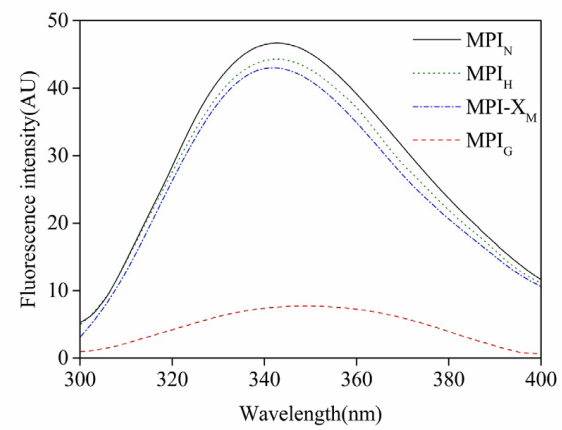

Figure 3. Intrinsic fluorescence spectra of $\mathrm{MPI}_{\mathrm{N}}, \mathrm{MPI}_{\mathrm{H}}, \mathrm{MPI}-\mathrm{X}_{\mathrm{M}}$, and $\mathrm{MPI}_{\mathrm{G}}$. that the occurrence of MR and the suggested reason are the attachments of xylose ostensibly entering MPI more polar and thus, suppressing the fluorescent emission of Trp residues (Guo \& Xiong, 2013). Moreover, a shielding effect caused by protein-bound xylose may also be responsible for the observed quenching of fluorescence intensity (Huang et al., 2012).

\subsection{SDS-PAGE}

The formation of MPI-xylose conjugates was confirmed via SDS-PAGE. Figure 4 shows the electrophoretic patterns of $\mathrm{MPI}_{\mathrm{N}}, \mathrm{MPI}_{\mathrm{H}}, \mathrm{MPI}-\mathrm{X}_{\mathrm{M}}$, and $\mathrm{MPI}_{\mathrm{G}}$. MPI $\mathrm{N}_{\mathrm{N}}$ exhibited several characteristic bands with molecular weights ranging from $14.4 \mathrm{kDa}$ to $97.4 \mathrm{kDa}$. For $\mathrm{MPI}_{\mathrm{H}}$, some native bands between 14.4 and $66.2 \mathrm{kDa}$ became shallow and a new thin band of larger molecular mass polymers appeared at the top of the stacking gel, which might be due to denaturation or aggregation of MPI being heated at $100^{\circ} \mathrm{C}$ (You et al., 2013). As expected, little or no changes were found in the MPI- $\mathrm{X}_{\mathrm{M}}$. It is worth noting that the SDS-PAGE pattern of MPI $_{G}$ was markedly different from others. Native bands of MPI diminished considerably, a new dark band and a new smear band appeared near the tops of the stacking and the running gels, respectively, indicating the formation of high-molecular-weight compounds. These results agreed with those found by Guan et al. (2010), who reported that the Maillard conjugation of protein and sugar cause both the appearance of the high-molecular-weight compounds and the appearance of a diffuse band.

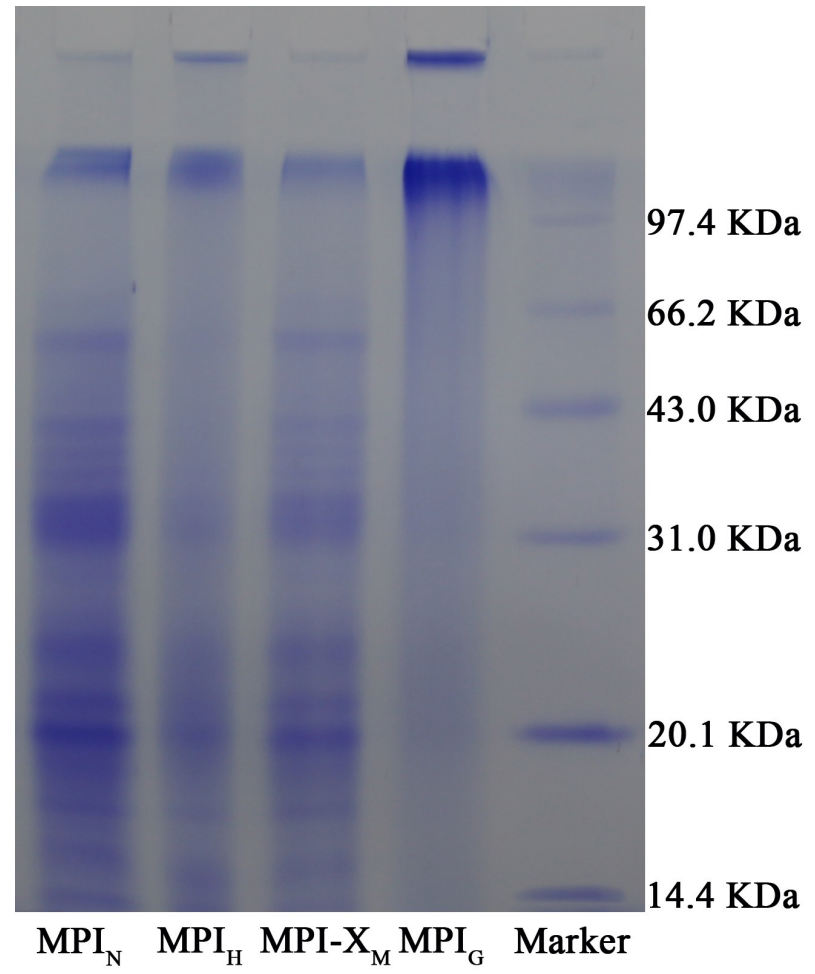

Figure 4. SDS-PAGE of $\mathrm{MPI}_{\mathrm{N}}, \mathrm{MPI}_{\mathrm{H}}, \mathrm{MPI}-\mathrm{X}_{\mathrm{M}}$, and $\mathrm{MPI}_{\mathrm{G}}$. 


\subsection{Amino acid composition}

In essence, the MR is the condensation of the reducing-end carbonyl of the reducing sugar and free amino groups of proteins. Therefore, the amino acid types involved in the MR and reduction degree of these amino acids can be confirmed by measuring the changes of amino acid components. Amino acid composition of $\mathrm{MPI}_{\mathrm{N}}, \mathrm{MPI}_{\mathrm{H}}, \mathrm{MPI}-\mathrm{X}_{\mathrm{M}}$, and $\mathrm{MPI}_{\mathrm{G}}$ are presented in Table 1 . The glutamic acid and aspartic acid in $\mathrm{MPI}_{\mathrm{N}}$ amounted to $81 \mathrm{mg} / \mathrm{g}$ and $70 \mathrm{mg} / \mathrm{g}$, respectively. The ratio of total essential amino acids (excluding tryptophan, which was completely lost during acid hydrolysis) to total amino acids (TAA) was $38 \%$, suggesting a high nutritional value. Compared to $\mathrm{MPI}_{\mathrm{N}}$, only few changes of amino acid components were observed in $\mathrm{MPI}_{\mathrm{H}}$ and MPI-X ${ }_{\mathrm{M}}$, while $\mathrm{MPI}_{\mathrm{G}}$ presented a $14 \%$ decrease of TAA. Especially the contents of several amino acids such as lysine, arginine and tyrosine were considerably reduced, $44 \%$ for lysine, $37 \%$ for arginine and $28 \%$ for tyrosine, respectively. This shows that these amino acids are involved in the carbonyl ammonia condensation reaction. According to a report by Gu et al. (2009), the lost amino groups during the MR largely originated from the side chains of lysine and arginine. The decrease in tyrosine content matched the remarkable decrease of fluorescence intensity in the $\mathrm{MPI}_{\mathrm{G}}$.

\subsection{Thermal properties}

DSC is often used to investigate thermal stabilities that can be reflected by the denaturation temperature $\left(\mathrm{T}_{\mathrm{p}}\right)$ and conformational stability that are correlated with the enthalpy value $(\Delta H)$ of proteins during heat treatment. Generally, the higher Tp and $\Delta \mathrm{H}$, the higher both thermal stability and conformational stability. The thermal properties of $\mathrm{MPI}_{\mathrm{N}}, \mathrm{MPI}_{\mathrm{H}}, \mathrm{MPI}-\mathrm{X}_{\mathrm{M}}, \mathrm{MPI}_{\mathrm{G}}$, and XYL are presented in Table 2 . MPI ${ }_{\mathrm{N}}$ exhibited a single endothermic transition between $47 \pm 1^{\circ} \mathrm{C}\left(\mathrm{T}_{\mathrm{o}}\right)$ and $151 \pm 4^{\circ} \mathrm{C}\left(\mathrm{T}_{\mathrm{c}}\right)$, with peak temperature $\left(\mathrm{T}_{\mathrm{p}}\right)$ and enthalpy change $(\Delta \mathrm{H})$ of $84 \pm 2{ }^{\circ} \mathrm{C}$ and $214 \pm 5 \mathrm{~J} / \mathrm{g}$, respectively. The $\mathrm{MPI}_{\mathrm{G}}$ presented a significantly higher $(P<0.05) \mathrm{T}_{\mathrm{p}}$ value than other protein samples, suggesting a significantly improved thermal stability of native protein via glycosylation modification. However, $\Delta \mathrm{H}$ was lower $(P<0.05)$ than that of $\mathrm{MPI}_{\mathrm{N}}$, but higher $(P<0.05)$ than those of $\mathrm{MPI}_{\mathrm{H}}$ and MPI- $\mathrm{X}_{\mathrm{M}}$. This means that the conformational stability of $\mathrm{MPI}_{\mathrm{G}}$ was better than those of $\mathrm{MPI}_{\mathrm{H}}$ and MPI-X $\mathrm{M}_{\mathrm{M}}$, but not as good as that of $\mathrm{MPI}_{\mathrm{N}}$, as a lower $\triangle \mathrm{H}$ value suggests less required energy for denaturation (Liu et al., 2012b). We speculate that conjugation with xylose can protect the protein against aggregation that results from heating or phase separation by blocking the hydrophobic binding sites on the surface (Huang et al., 2012),

Table 1. Amino acid composition of $\mathrm{MPI}_{\mathrm{N}}, \mathrm{MPI}_{\mathrm{H}}, \mathrm{MPI}-\mathrm{X}_{\mathrm{M}}$, and $\mathrm{MPI}_{\mathrm{G}}$.

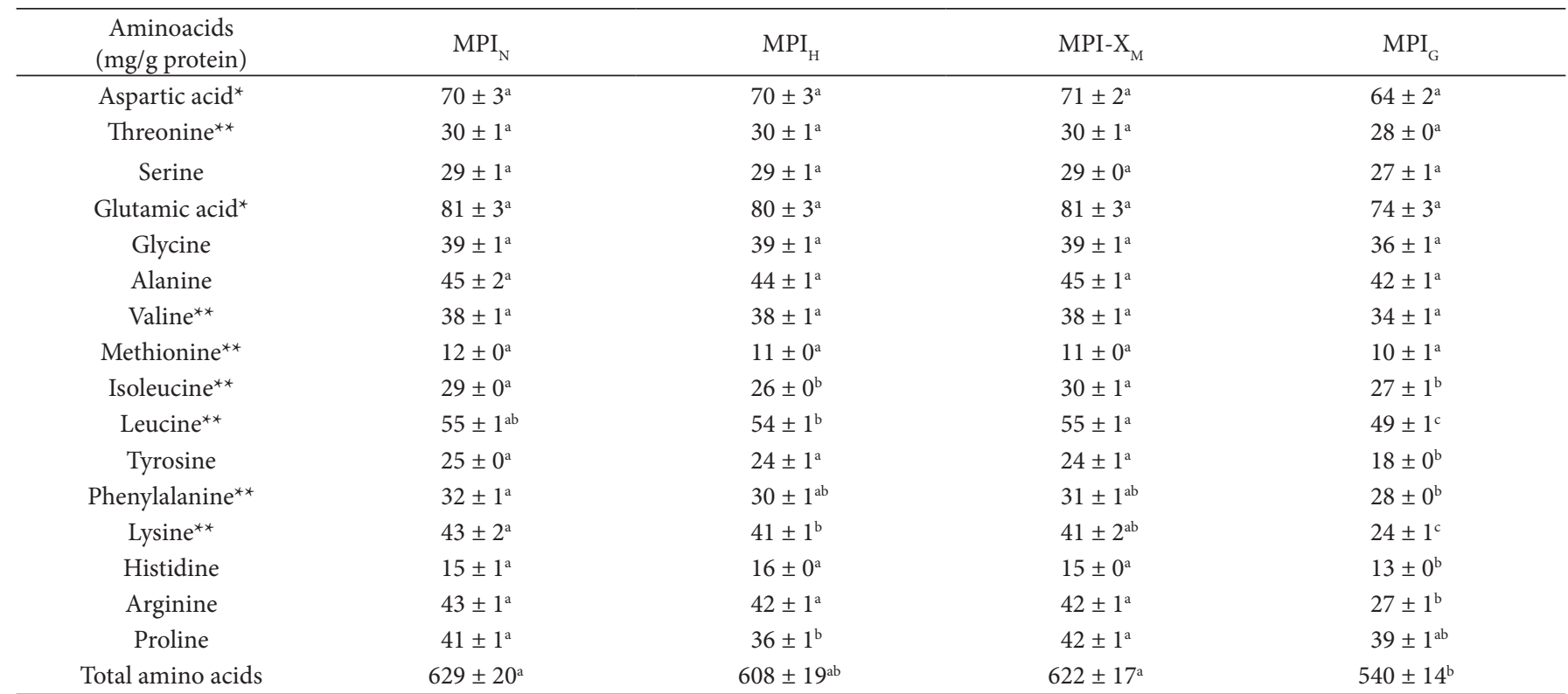

Data are shown as means \pm SD $(n=3)$. Different superscript letters within the same row denote significant differences $(P<0.05) ;{ }^{\star}$ The contents of aspartic and glutamic acid include asparaginate and glutamine; ${ }^{* *}$ Essential amino acids, excluding tryptophan.

Table 2. Thermal properties of $\mathrm{MPI}_{\mathrm{N}}, \mathrm{MPI}_{\mathrm{H}}, \mathrm{MPI}-\mathrm{X}_{\mathrm{M}}, \mathrm{MPI}_{\mathrm{G}}$, and $\mathrm{XYL}_{\mathrm{N}}$ evaluated via DSC.

\begin{tabular}{crrrc}
\hline Sample & $\mathrm{T}_{\mathrm{o}}\left({ }^{\circ} \mathrm{C}\right)$ & $\mathrm{T}_{\mathrm{p}}\left({ }^{\circ} \mathrm{C}\right)$ & $\mathrm{T}_{\mathrm{c}}\left({ }^{\circ} \mathrm{C}\right)$ & $\Delta \mathrm{H}(\mathrm{J} / \mathrm{g})$ \\
\hline $\mathrm{MPI}_{\mathrm{N}}$ & $47 \pm 1^{\mathrm{b}}$ & $84 \pm 2^{\mathrm{d}}$ & $151 \pm 4^{\mathrm{a}}$ & $123 \pm 2^{\mathrm{b}}$ \\
MPI $_{\mathrm{H}}$ & $48 \pm 1^{\mathrm{b}}$ & $82 \pm 2^{\mathrm{d}}$ & $130 \pm 5^{\mathrm{b}}$ & $153 \pm 3^{\mathrm{c}}$ \\
${\mathrm{MPI}-\mathrm{X}_{\mathrm{M}}}^{\mathrm{b}}$ & $51 \pm 3^{\mathrm{b}}$ & $92 \pm 3^{\mathrm{c}}$ & $126 \pm 5^{\mathrm{b}}$ & $160 \pm 5^{\mathrm{c}}$ \\
$\mathrm{MPI}_{\mathrm{G}}$ & $54 \pm 2^{\mathrm{b}}$ & $101 \pm 3^{\mathrm{b}}$ & $160 \pm 7^{\mathrm{a}}$ & $173 \pm 3^{\mathrm{b}}$ \\
$\mathrm{XYL}_{\mathrm{N}}$ & $150 \pm 4^{\mathrm{a}}$ & $155 \pm 5^{\mathrm{a}}$ & $218 \pm 4^{\mathrm{a}}$ \\
\hline
\end{tabular}

Data are shown as means $\pm \mathrm{SD}(\mathrm{n}=3)$. Different superscript letters within the same column denote significant differences $(P<0.05)$. $\mathrm{T}_{\mathrm{o}}=$ onset temperature; $\mathrm{T}_{\mathrm{p}}=$ peak temperature; $\mathrm{T}_{\mathrm{c}}=$ conclusion temperature; $\Delta \mathrm{H}=$ enthalpy change. 

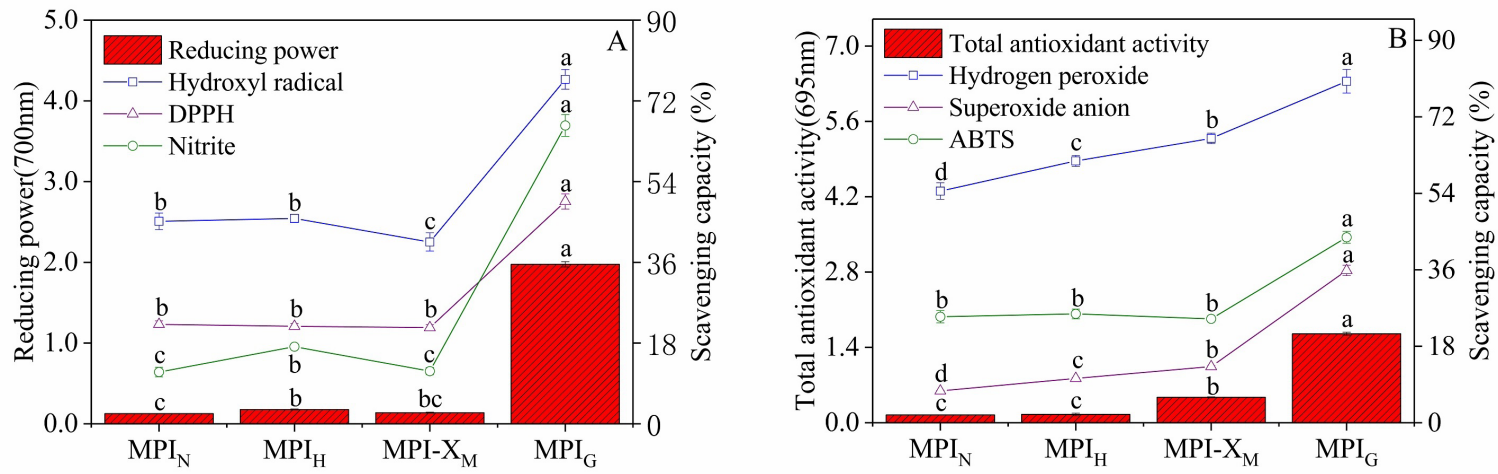

Figure 5. Antioxidant activity of $\mathrm{MPI}_{\mathrm{N}}, \mathrm{MPI}_{\mathrm{H}}, \mathrm{MPI}-\mathrm{X}_{\mathrm{M}}$, and $\mathrm{MPI}_{\mathrm{G}^{*}}$ (A) Reducing power and scavenging capacity of nitrite, DPPH, and hydroxyl radicals. (B) Total antioxidant activity and scavenging capacity of hydrogen peroxide, superoxide anions, and ABTS radicals.

while strengthening electrostatic repulsion (He, 2015), and thus boosting the thermal stability of the protein. The reduction in $\Delta \mathrm{H}$ indicates partial unfolding of the tertiary structure, mainly due to a disruption of the intramolecular forces, such as hydrogen bonds and hydrophobic interactions of MPI when conjugated with xylose via covalent bonds. Similar results were observed during the glycation of bovine serum albumin (Kim \& Shin, 2016).

\subsection{In vitro antioxidant activity}

Due to the diversity of antioxidant activity of MRPs, eight different systems, that determine various aspects of antioxidant capacity, were employed to investigate the antioxidant activities of $\mathrm{MPI}_{\mathrm{N}}, \mathrm{MPI}_{\mathrm{H}}, \mathrm{MPI}-\mathrm{X}_{\mathrm{M}}$, and $\mathrm{MPI}_{\mathrm{G}}$. The results are illustrated in Figure 5. As expected, the total antioxidant capacity and reducing power of $\mathrm{MPI}_{\mathrm{G}}$ were 11 and 16 times higher than those of MPI ${ }_{N}$. Nitrite-scavenging activity increased by $476 \%$ and a $47 \%$ increase in hydrogen peroxide scavenging activity was also observed in comparison to the MPI ${ }_{N}$. Compared to MPI ${ }_{N}$, the scavenging abilities on DPPH, ABTS, superoxide anions, and hydroxyl radicals of $\mathrm{MPI}_{\mathrm{G}}$ were all markedly increased by $124 \%, 75 \%, 379 \%$, and $70 \%$, respectively. These results indicate that antioxidant activity of MPI was significantly enhanced by glycation modification with xylose via MR. Additionally, MPI $_{\mathrm{H}}$ presented a slight increase in reducing power and scavenging activities on the superoxide anion, nitrite and hydrogen peroxide. MPI- $\mathrm{X}_{\mathrm{M}}$ also showed improved total antioxidant and scavenging activity against superoxide anions and hydrogen peroxide, compared to native MPI. However, all these activities were much lower than those of $\mathrm{MPI}_{\mathrm{G}}$, indicating that the antioxidant activity of MPI was affected either by heating or adding xylose. The increase of antioxidant activity in $\mathrm{MPI}_{\mathrm{H}}$ and MPI-X $\mathrm{X}_{\mathrm{M}}$ may be attributed to changes in the tertiary structure of the protein as suggested by the results of the fluorescence analysis. The improvement of antioxidant activity in MPI-X might also be caused by the addition of xylose, because it is a reducing sugar with a certain antioxidant activity. Interestingly, MPI- $\mathrm{X}_{\mathrm{M}}$ showed a reduced hydroxyl radical scavenging activity compared to native MPI. This result might be attributed to the masking effect of xylose, formed by intermolecular hydrogen bonds, which blocked the role that MPI-X ${ }_{\mathrm{M}}$ exerts on functional groups (Wang \& Wang, 2015). Existing research demonstrated that MRPs from xylose and a small number of compounds that contain amino groups, such as whey protein (Wang et al., 2013), chitosan (Zhu et al., 2013), as well as glycine (Yin et al., 2014b) have been endowed with dramatically higher antioxidant activity, including reducing power, DPPH radical-scavenging activity, and ABTS radical-scavenging activity. These findings coincide with a high antioxidant activity of $\mathrm{MPI}_{\mathrm{G}}$ as shown in Figure 5. It has been reported that the intermediate reductones, advanced melanoidins, and heterocyclic compounds from MRPs are key antioxidant components (Yin et al., 2014b), presenting high antioxidant activity mainly through chain-breaking, electron and hydrogen atom donation, metal-chelating, and oxygen-scavenging mechanisms (Kim \& Lee, 2009; Wu et al., 2014). In addition, The MRPs contained more effective reducing structures, such as hydroxyl groups, due to a destruction of intermolecular hydrogen bonds, which also accounts for increased antioxidant activity (Luo et al., 2013).

\section{Conclusion}

WPI-xylose conjugates were prepared via MR and the conjugation between WPI and xylose was confirmed via FT-IR and intrinsic fluorescence analysis. The analysis of amino acid composition demonstrated that lysine, arginine, and tyrosine in MPI were largely bound to xylose. DSC results show an improved thermal stability of MPI due to xylose modification. Additionally, it was established that MPI-xylose conjugates $\left(\mathrm{MPI}_{\mathrm{G}}\right)$ present significantly enhanced antioxidant activity when compared to native MPI $\left(\mathrm{MPI}_{\mathrm{N}}\right)$, heated MPI $\left(\mathrm{MPI}_{\mathrm{H}}\right)$, and an unheated mixture of MPI and xylose $\left(\mathrm{MPI}-\mathrm{X}_{\mathrm{M}}\right)$. Consequently, $\mathrm{MPI}_{\mathrm{G}}$ should be acknowledged as promising protein antioxidant with possible applications in the field of nutraceutical and functional food ingredients. Further investigations should be directed to establishing whether the harmful advanced glycation end products are produced during the glycation of MPI, If yes, then it would be interesting to know how many advanced glycation end products are produced and how their production can be controlled and how to remove them from the glycation system. In addition, the identification of the structure of the active compounds in the $\mathrm{MPI}_{\mathrm{G}}$, in vivo antioxidant activity of $\mathrm{MPI}_{\mathrm{G}}$ and signaling pathways associated with antioxidant activity is also required. 


\section{Acknowledgements}

This work was financially supported by the Postgraduate Research \&Practice Innovation Program of Jiangsu Province (KYLX15_0916), the Doctorate Fellowship Foundation of the Nanjing Forestry University, the Natural Science Foundation of Anhui Provincial Department of Education (KJ2017A515), and the Program of Key Discipline in Anhui Science and Technology University (AKZDXK2015B02).

\section{References}

Al-Amiery, A. A., Al-Majedy, Y. K., Kadhum, A. A. H., \& Mohamad, A. B. (2015). Hydrogen peroxide scavenging activity of novel coumarins synthesized using different approaches. PLoS One, 10(7), e0132175. PMid:26147722. http://dx.doi.org/10.1371/journal.pone.0132175.

Elias, R. J., Kellerby, S. S., \& Decker, E. A. (2008). Antioxidant activity of proteins and peptides. Critical Reviews in Food Science and Nutrition, 48(5), 430-441. PMid:18464032. http://dx.doi. org/10.1080/10408390701425615.

Farhat, I. A., Orset, S., Moreau, P., \& Blanshard, J. M. (1998). FTIR study of hydration phenomena in protein-sugar systems. Journal of Colloid and Interface Science, 207(2), 200-208. PMid:9792763. http://dx.doi.org/10.1006/jcis.1998.5751.

Fu, R., Zhang, Y., Guo, Y., \& Chen, F. (2014). Antioxidant and tyrosinase inhibition activities of the ethanol-insoluble fraction of water extract of Sapium sebiferum (L.) Roxb. leaves. South African Journal of Botany, 93, 98-104. http://dx.doi.org/10.1016/j.sajb.2014.04.003.

García-Pascual, P., Sanjuán, N., Melis, R., \& Mulet, A. (2006). Morchella esculenta (morel) rehydration process modelling. Journal of Food Engineering, 72(4), 346-353. http://dx.doi.org/10.1016/j. jfoodeng.2004.12.014.

Geng, X., Cui, B., Li, Y., Jin, W., An, Y., Zhou, B., Ye, T., He, L., Liang, H. S., Wang, L., Chen, Y. J., \& Li, B. (2014). Preparation and characterization of ovalbumin and carboxymethyl cellulose conjugates via glycosylation. Food Hydrocolloids, 37, 86-92. http:// dx.doi.org/10.1016/j.foodhyd.2013.10.027.

Gu, F., Kim, J. M., Hayat, K., Xia, S., Feng, B., \& Zhang, X. (2009). Characteristics and antioxidant activity of ultrafiltrated Maillard reaction products from a casein-glucose model system. Food Chemistry, 117(1), 48-54. http://dx.doi.org/10.1016/j.foodchem.2009.03.074.

Guan, Y. G., Lin, H., Han, Z., Wang, J., Yu, S. J., Zeng, X. A., Liu, Y. Y., Xu, C. H., \& Sun, W. W. (2010). Effects of pulsed electric field treatment on a bovine serum albumin-dextran model system, a means of promoting the Maillard reaction. Food Chemistry, 123(2), 275-280. http://dx.doi.org/10.1016/j.foodchem.2010.04.029.

Guo, X., \& Xiong, Y. L. (2013). Characteristics and functional properties of buckwheat protein-sugar Schiff base complexes. LebensmittelWissenschaft + Technologie, 51(2), 397-404. http://dx.doi.org/10.1016/j. lwt.2012.12.003.

He, Y. (2015). Improved heat stability of whey protein isolate by glycation with inulin (Master's thesis). University of Missouri, Columbia.

Huang, X., Tu, Z., Xiao, H., Wang, H., Zhang, L., Hu, Y., Zhang, Q. T., \& Niu, P. (2012). Characteristics and antioxidant activities of ovalbumin glycated with different saccharides under heat moisture treatment. Food Research International, 48(2), 866-872. http://dx.doi. org/10.1016/j.foodres.2012.06.036.

Kim, D. Y., \& Shin, W. S. (2015). Characterisation of bovine serum albumin-fucoidan conjugates prepared via the Maillard reaction. Food Chemistry, 173, 1-6. PMid:25465988. http://dx.doi.org/10.1016/j. foodchem.2014.09.167.
Kim, D. Y., \& Shin, W. S. (2016). Functional improvements in bovine serum albumin-fucoidan conjugate through the Maillard reaction. Food Chemistry, 190, 974-981. PMid:26213064. http://dx.doi. org/10.1016/j.foodchem.2015.06.046.

Kim, J. S., \& Lee, Y. S. (2009). Antioxidant activity of Maillard reaction products derived from aqueous glucose/glycine, diglycine, and triglycine model systems as a function of heating time. Food Chemistry, 116(1), 227-232. http://dx.doi.org/10.1016/j.foodchem.2009.02.038.

Laemmli, U. K. (1970). Cleavage of structural proteins during the assembly of the head of bacteriophage T4. Nature, 227(5259), 680685. PMid:5432063. http://dx.doi.org/10.1038/227680a0.

LeDuy, A., Kosaric, N., \& Zajic, J. E. (1974). Morel mushroom mycelium growth in waste sulfite liquors as source of protein and flavouring. Canadian Institute of Food Science and Technology Journal, 7(1), 44-50. http://dx.doi.org/10.1016/S0315-5463(74)73845-7.

Li, Y., Lu, F., Luo, C., Chen, Z., Mao, J., Shoemaker, C., \& Zhong, F. (2009). Functional properties of the Maillard reaction products of rice protein with sugar. Food Chemistry, 117(1), 69-74. http://dx.doi. org/10.1016/j.foodchem.2009.03.078.

Liu, D., Sheng, J., Li, Z., Qi, H., Sun, Y., Duan, Y., \& Zhang, W. (2013). Antioxidant activity of polysaccharide fractions extracted from Athyrium multidentatum (Doll.) Ching. International Journal of Biological Macromolecules, 56, 1-5. PMid:23357796. http://dx.doi. org/10.1016/j.ijbiomac.2013.01.023.

Liu, J., Ru, Q., \& Ding, Y. (2012a). Glycation a promising method for food protein modification: Physicochemical properties and structure, a review. Food Research International, 49(1), 170-183. http://dx.doi. org/10.1016/j.foodres.2012.07.034.

Liu, Q., Kong, B., Han, J., Sun, C., \& Li, P. (2014). Structure and antioxidant activity of whey protein isolate conjugated with glucose via the Maillard reaction under dry-heating conditions. Food Structure, 1(2), 145-154. http://dx.doi.org/10.1016/j.foostr.2013.11.004.

Liu, Y., Zhao, G., Zhao, M., Ren, J., \& Yang, B. (2012b). Improvement of functional properties of peanut protein isolate by conjugation with dextran through Maillard reaction. Food Chemistry, 131(3), 901-906. http://dx.doi.org/10.1016/j.foodchem.2011.09.074.

Luo, Y., Ling, Y., Wang, X., Han, Y., Zeng, X., \& Sun, R. (2013). Maillard reaction products from chitosan-xylan ionic liquid solution. Carbohydrate Polymers, 98(1), 835-841. PMid:23987419. http:// dx.doi.org/10.1016/j.carbpol.2013.06.023.

Meng, F., Liu, X., Jia, L., Song, Z., Deng, P., \& Fan, K. (2010). Optimization for the production of exopolysaccharides from Morchella esculenta SO-02 in submerged culture and its antioxidant activities in vitro. Carbohydrate Polymers, 79(3), 700-704. http://dx.doi.org/10.1016/j. carbpol.2009.09.032.

Oliver, C. M., Melton, L. D., \& Stanley, R. A. (2006). Creating proteins with novel functionality via the Maillard reaction: a review. Critical Reviews in Food Science and Nutrition, 46(4), 337-350. PMid:16621753. http://dx.doi.org/10.1080/10408690590957250.

Rajendran, P., Nandakumar, N., Rengarajan, T., Palaniswami, R., Gnanadhas, E. N., Lakshminarasaiah, U., Gopas, J., \& Nishigaki, I. (2014). Antioxidants and human diseases. Clinica Chimica Acta, 436, 332-347. PMid:24933428. http://dx.doi.org/10.1016/j.cca.2014.06.004.

Salla, S., Sunkara, R., Ogutu, S., Walker, L. T., \& Verghese, M. (2016). Antioxidant activity of papaya seed extracts against $\mathrm{H} 2 \mathrm{O} 2$ induced oxidative stress in HepG2 cells. Lebensmittel-Wissenschaft + Technologie, 66, 293-297. http://dx.doi.org/10.1016/j.lwt.2015.09.008.

Spotti, M. J., Martinez, M. J., Pilosof, A. M. R., Candioti, M., Rubiolo, A. C., \& Carrara, C. R. (2014a). Influence of Maillard conjugation on structural characteristics and rheological properties of whey 
protein/dextran systems. Food Hydrocolloids, 39, 223-230. http:// dx.doi.org/10.1016/j.foodhyd.2014.01.014.

Spotti, M. J., Martinez, M. J., Pilosof, A. M. R., Candioti, M., Rubiolo, A. C., \& Carrara, C. R. (2014b). Rheological properties of whey protein and dextran conjugates at different reaction times. Food Hydrocolloids, 38, 76-84. http://dx.doi.org/10.1016/j.foodhyd.2013.11.017.

Sun, Y., Hayakawa, S., Chuamanochan, M., Fujimoto, M., Innun, A., \& Izumori, K. (2006). Antioxidant effects of Maillard reaction products obtained from ovalbumin and different D-aldohexoses. Bioscience, Biotechnology, and Biochemistry, 70(3), 598-605. PMid:16556974. http://dx.doi.org/10.1271/bbb.70.598.

Tu, Z. C., Hu, Y. M., Wang, H., Huang, X. Q., Xia, S. Q., \& Niu, P. P. (2015). Microwave heating enhances antioxidant and emulsifying activities of ovalbumin glycated with glucose in solid-state. Journal of Food Science and Technology-Mysore, 52(3), 1453-1461. PMid:25745213. http://dx.doi.org/10.1007/s13197-013-1120-x.

Wang, W. Q., Bao, Y. H., \& Chen, Y. (2013). Characteristics and antioxidant activity of water-soluble Maillard reaction products from interactions in a whey protein isolate and sugars system. Food Chemistry, 139(1-4), 355-361. PMid:23561117. http://dx.doi. org/10.1016/j.foodchem.2013.01.072.

Wang, Y., \& Wang, X. (2015). Binding, stability, and antioxidant activity of quercetin with soy protein isolate particles. Food Chemistry, 188, 24-29. PMid:26041159. http://dx.doi.org/10.1016/j.foodchem.2015.04.127.

Wu, S., Hu, J., Wei, L., Du, Y., Shi, X., \& Zhang, L. (2014). Antioxidant and antimicrobial activity of Maillard reaction products from xylan with chitosan/chitooligomer/glucosamine hydrochloride/taurine model systems. Food Chemistry, 148, 196-203. PMid:24262546. http://dx.doi.org/10.1016/j.foodchem.2013.10.044.

Xue, F., Li, C., Zhu, X., Wang, L., \& Pan, S. (2013). Comparative studies on the physicochemical properties of soy protein isolate-maltodextrin and soy protein isolate-gum acacia conjugate prepared through Maillard reaction. Food Research International, 51(2), 490-495. http://dx.doi.org/10.1016/j.foodres.2013.01.012.

Yang, X., Yan, F., Huang, S., \& Fu, C. (2014). Antioxidant activities of fractions from longan pericarps. Food Science and Technology
(Campinas), 34(2), 341-345. http://dx.doi.org/10.1590/S010120612014005000034.

Yin, C., Yang, L., Zhao, H., \& Li, C. P. (2014a). Improvement of antioxidant activity of egg white protein by phosphorylation and conjugation of epigallocatechin gallate. Food Research International, 64, 855-863. http://dx.doi.org/10.1016/j.foodres.2014.08.020.

Yin, Z., Sun, Q., Zhang, X., \& Jing, H. (2014b). Optimised formation of blue Maillard reaction products of xylose and glycine model systems and associated antioxidant activity. Journal of the Science of Food and Agriculture, 94(7), 1332-1339. PMid:24173610. http:// dx.doi.org/10.1002/jsfa.6415.

You, J., Luo, Y., \& Shen, H. (2013). Functional properties of water-soluble proteins from silver carp (Hypophthalmichthys molitrix) conjugated with five different kinds of sugar. Food and Bioprocess Technology, 6(12), 3596-3603. http://dx.doi.org/10.1007/s11947-012-1036-x.

You, J., Luo, Y., \& Wu, J. (2014). Conjugation of ovotransferrin with catechin shows improved antioxidant activity. Journal of Agricultural and Food Chemistry, 62(12), 2581-2587. PMid:24606536. http:// dx.doi.org/10.1021/jf405635q.

Zhang, J., Wu, N., Lan, T., \& Yang, X. (2014). Improvement in emulsifying properties of soy protein isolate by conjugation with maltodextrin using high-temperature, short-time dry-heating Maillard reaction. International Journal of Food Science \& Technology, 49(2), 460-467. http://dx.doi.org/10.1111/ijfs.12323.

Zhu, K. X., Li, J., Li, M., Guo, X. N., Peng, W., \& Zhou, H. M. (2013). Functional properties of chitosan-xylose Maillard reaction products and their application to semi-dried noodle. Carbohydrate Polymers, 92(2), 1972-1977. PMid:23399246. http://dx.doi.org/10.1016/j. carbpol.2012.11.078.

Zhuang, H., Tang, N., \& Yuan, Y. (2013). Purification and identification of antioxidant peptides from corn gluten meal. Journal of Functional Foods, 5(4), 1810-1821. http://dx.doi.org/10.1016/j.jff.2013.08.013. 